\title{
Breeding vegetatively propagated horticultural crops
}

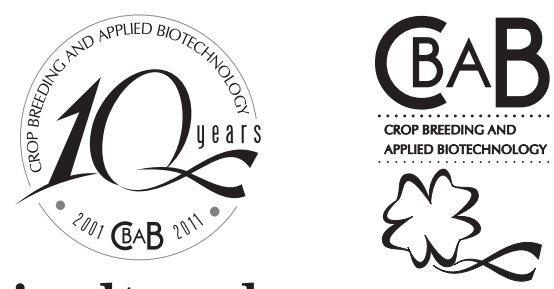

Dilson Antônio Bisognin ${ }^{1 *}$

Received 28 March 2011

Accepted 18 May 2011

\begin{abstract}
Horticulture is an important part of agriculture with many important crops being vegetatively propagated. The objectives of this work were to discuss some of the most important characteristics of vegetatively propagated crops and the breeding strategies to develop and propagate new cultivars. Vegetative propagation enables to fix favorable combinations of important traits, very specific chemical compositions, superior genetic variance interactions and high levels of heterozygosity. Breeding new cultivars involve few possibilities of genetic recombination by sexual reproduction and many generations of selection and vegetative propagation. Marker assisted selection should be useful for genotyping and selecting complementary parents for crossing and for identifying superior genotypes at early stages of selection. The tissue culture technique enables to get disease free stock plants and to maximize its multiplication rate, having an important role in yield and quality of these crops.
\end{abstract}

Key words: root and tuber crops, micropropagation, rapid propagation, clonal selection, new cultivars.

\section{INTRODUCTION}

Horticulture, an important part of agriculture, refers to the production of fruits, vegetables, flowers, ornamentals, medicinal and aromatic plants and includes many services, which promote the management, production and marketing. Horticulture has established its importance in many aspects of innovation, improving land use, promoting crop diversification, generating employment and providing nutritional security to the people (Sonah et al. 2011). Many horticultural crops are vegetatively propagated, because it makes possible to fix and multiply favorable genetic combinations.

Vegetative or clonal propagation is an asexual reproduction in which successive mitosis of specialized vegetative propagules (as bulbs, corms, tubers, cuttings, buds and apomictic seeds) develop new plants and results in a clonal population. Clone is defined as a genetically uniform material derived from a single individual that is vegetatively propagated either in vivo or in vitro. In species cultivated for vegetative products, as potato (Solanum tuberosum), cassava (Manihot esculenta) and sweet potato (Ipomea batatas), the flowering and fertility are reduced and less important in a new clone. In these species there is a competition between consumption and vegetative propagules. One hectare of potatoes demands two tons of tubers with the average size of $50 \mathrm{~g}$. However, in species cultivated for fruit or reproductive product, as strawberry (Fragaria X ananassa), fruit yield and quality are very important traits. As most of these crops combine sexual and asexual reproduction, there is a wide genetic variation among species and populations, depending upon

\footnotetext{
${ }^{1}$ Universidade Federal de Santa Maria (UFSM), Departamento de Fitotecnia, Melhoramento e Propagação Vegetativa de Plantas, Av. Roraima, 1000, 97.105900, Camobi, Santa Maria, RS, Brazil.*E-mail: dilsonb@smail.ufsm.br
} 
the relative importance of sexual and asexual reproduction (Eckert 2002).

Some vegetatively propagated horticultural species are among the most important food crops. The Food and Agriculture Organization ranks potato as the fourth crop after wheat, maize and rice and cassava as the sixth crop after barley. Potato has being recognized as the world's major staple crop, produces more dry matter and protein per hectare than the major cereal crops and has the protein with the highest biological quality. Besides a staple food, potato is grown as a vegetable for table use and processed in to French fries, chips and an increasingly wide range of frozen and chilled products. It is also used for dried products and starch production. Cassava is the primary staple for more than 800 million people in the world, mostly in the poorest tropical countries. Cassava plays an essential food security role, because it matured edible roots can be left in the ground for up to 36 months (Lebot 2009). Sweet potato ranks the seventh crop, just after cassava. Its storage roots are rich in carbohydrates and vitamin A and its leaves are rich in proteins. Sweet potato has diverse uses, ranging from consumption of fresh roots or leaves to processing into animal feed, starch, ûour, noodles, natural colorants, candy and alcohol. Yams (Dioscorea spp.) provide the staple food for millions of people in Africa, South America, Asia and the Paciûc tropical countries. The underground storage organs are tubers that can be stored for four to six months after harvesting without signiûcant deterioration of their nutritional properties. These root and tuber crops are among the oldest on earth and they were the only staples and fed big populations before the introduction of cereals in developing countries. Today they represent the second set of food crops after cereals (Lebot 2009).

The objectives of this work were to discuss some of the most important characteristics of vegetatively propagated crops and the breeding strategies to develop and propagate new cultivars.

\section{IMPORTANT CHARACTERISTIS OF VEGETATIVELY PROPAGATED CROPS}

Vegetative propagation enables to fix favorable combinations of important traits, very specific chemical compositions and superior genetic variance interactions. It also preserves high levels of heterozygosity, a unique characteristic of such plants that is necessary for high hybrid vigor (Glémin et al. 2006). Favorable spontaneous and induced mutations can easily be identified and propagated (Nybom 1961). Undesirable crosses and the deleterious effects of wild to crop gene flow are easily controlled. Vegetative propagation allows multiplying cultivars that produce no viable seeds. Propagation of some species is easier, more rapid, and more economical by vegetative methods than by true seeds (McKey et al. 2010). Species as potato can be vegetatively propagated by tubers and cuttings. The advantages of cuttings are the rapid mass propagation of selected clones and propagation may be done in both in vitro and ex vitro, which increases the propagation rate.

The high heterozygosity and hybrid vigor make the vegetatively propagated crops very vulnerable to inbreeding depression, thus they are not submitted to selfpollination. The inbreeding depression in autopoliploids, as the cultivated autotetraploid potato, exceeds twice that predicted by the inbreeding coefficient. This response has been attributed to a decrease in favorable interactions of second and third order and a frequency reduction of tetragenic and trigenic loci. Autopoliploid species can also accumulate a greater number of masked deleterious recessive alleles than diploid species, because of the multiallelism (Bradshaw 1994).

The result of the breeding process is a drastic reduction of genetic variability and only the best performing genotypes or even species are cloned. More than $97 \%$ of the world potato production is based upon the autotetraploid $S$. tuberosum subsp. tuberosum, only one subspecies from seven cultivated species that includes diploid $(2 n=2 x=24)$, triploid $(2 n=3 x=36)$, tetraploid $(2 n=4 x=48)$ and pentaploid $(2 n=5 x=60)$ (Hawkes 1990). High uniformity usually leads to high yield and genotype by environmental interaction. A clone has the same environmental need at the same time and also the same level of pathogen reaction, which under stress may reduce yield and production quality.

Vegetatively propagated crops may have important source of phenotypic variation from transgenerational epigenetic inheritance. Epigenetic inheritance is a variation transmitted from mother to daughter cell not resulting from differences in DNA base sequences and/or in present environmental conditions (Jablonka and Raz 2009). The effects of bud position along the stem, bud age and environmental and/or rootstock of the excised tissue are transgenerational epigenetic inheritance, respectively described as topophysis, cyclophysis and periphysis (Klaehn 1963). In roses (Rosa hybrida), cuttings excised 
from lower medial position along the shoot originated plants with a higher fresh weight, greater flower stem diameter and specific fresh weight than those plants originated from apical or basal positions (Bredmose and Hansen 1996).

One hypothesis of the domestication syndrome of the vegetatively propagated crops is almost an instantaneous and simple process of selecting and propagating superior genotypes. Domesticated populations have had very few recombination and selection cycles to differentiate from their wild relatives (Zohary 2004). Therefore, only a mix of sexual and asexual reproduction system would be able to generate so ample opportunity for the accumulation of domesticated traits. Seed propagation would increase the genetic diversity and vegetative propagation would fix superior hybrid combinations and increase its frequency in the population, resulting in a confusing diversity of domestication syndromes (McKey et al. 2010). These distinctive features have direct implications in the breeding programs of vegetatively propagated horticultural crops.

\section{BREEDING STRATEGIES AND DEVELOPMENT OF NEW CULTIVARS}

The possibility of combining sexual and asexual reproduction systems in almost all vegetatively propagated horticultural crops is the key strategy to develop new cultivars, because hybridization is the best approach to increase genetic diversity and combine traits in an individual (Hancock 2004). The identification of one genotype with superior hybrid combination is sufficient, because vegetative propagation fixes its heterozygosity and non-additive interactions and allows its multiplication, even of sterile genotypes. Adequate breeding strategies and population size enable fully exploitation of general and specific combining ability that result in high hybrid vigor (McKey et al. 2010). Therefore, a reasonable breeding strategy would be to exploit as much as possible the gene pool diversity. Increasing genetic variability in the cultivated germplasm would reduce the crop vulnerability, increase the gain from selection and allow the incorporation of specific traits in new cultivars.

\section{Gene introgression to cultivated germplasm}

The potato probably has the widest genetic diversity among related wild species than any other cultivated plant, with the vast majority (74\%) of the diploid species, and the rest being triploid, tetraploid, pentaploid, and hexaploid
(Hawkes 1990). Despite the low level of genome differentiation in most Solanum species, the germplasm can not all be directly used for breeding due to a combination of ploidy level and endosperm balance number (EBN) incompatibility (Hawkes and Jackson 1992). The majority of the diploid wild species can be directly crossed with dihaploids $(2 n=$ $2 x=24$ ) of cultivated potato. Dihaploids occur as a result of parthenogenesis (haploid pollinator technique) or anther culture (Hermsen 1994). Dihaploid x wild species hybrids can be crossed with cultivated potato via unilateral sexual polyploidization ( $4 x-2 x$ crosses) using $2 n$ gametes. Also, two dihaploid $\mathrm{x}$ wild species hybrids that produce $2 n$ pollen and $2 n$ eggs can be crossed in a bilateral sexual polyploidization ( $2 x-2 x$ crosses) to create novel tetraploids (Hermsen 1994, Hanneman 1999). It is reasonable that the wild parent should be selected for important traits as tuberization, tuber quality traits, tolerance to environmental stresses and resistance to diseases and pests, sexual fertility and $2 n$ gamete production before crossing with dihaploids. Therefore, the knowledge and use of endosperm balance number, dihaploids and $2 n$ gametes made available a wide range of the Solanum genetic diversity to potato breeders (Hanneman 1999).

This breeding strategy was used for the introgression of late blight (Phytophthora infestans) resistance from the wild diploid species $S$. microdontum $(2 n=4 x=24$ e $2 \mathrm{EBN})$ to cultivated potato $(2 n=4 x=48$ e $4 \mathrm{EBN})$. A total of 175 clones from six accessions of $S$. microdontum were evaluated against the US 8 genotype / A2 matting type of $P$. infestans and 27 highly resistant ones were selected (Douches et al. 2001). The most distinct clones from cultivated potato (Bisognin and Douches 2002a) were crossed with a susceptible dihaploid and the most segregating progenies selected for genetic studies. The progeny of the cross between the dihaploid MSA133-57 [(S. tuberosum x $S$. chacoense) x $S$. phureja $]$ and $S$. microdontum (PI595511-5) was mapped and selected for late blight resistance, vine maturity, chip color, tuber appearance, specific gravity and $2 n$ pollen production. One selected clone from the progeny was used for unilateral poliploidization $(4 x-2 x$ crosses) to introgress genes to cultivated germplasm. The quantitative trait loci conferring late blight resistance in $S$. microdontum could be followed through poliploidization and the identified microsatellite used in a marker assisted selection program to introgress the resistance gene from a wild species to cultivated potato (Bisognin et al. 2005). As done for late blight resistance, other important traits can be followed through poliploidization 
to increase the genetic gain in a marker assisted selection program of multiple traits to increase the genetic diversity of cultivated potato.

In potato there are other successful gene introgressions of specific traits from wild species. Resistance genes against late blight from $S$. demissum and S. stoloniferum, viruses from $S$. chacoense and $S$. acaule, and potato cyst nematodes from S. vernei and S. spegazzinii were introgressed. Some hybrids involving wild species and cultivated $S$. tuberosum subsp. andigena and $S$. phureja were extensively used in breeding new cultivars in Europe (Ross 1986). Even with all these breeding efforts and the wide genetic diversity, only seven wild potato species are present in the pedigree of the cultivars developed by the breeding program of the Scottish Crop Research Institute. Solanum demissum is in the pedigree of 58 cultivars conferring resistance to late blight, $S$. vernei is in 19 cultivars for nematode resistance, and $S$. microdontum is in 15 cultivars for potato virus Y resistance. The other four species $(S$. multidissectum, S. commersonii, S. maglia and S. acaule) are conferring resistance to other fungal and bacterial diseases without a deliberate breeding effort (Bradshaw 2009). Potato clones with different wild genome composition were selected with high specific gravity, yield and set of large tubers and good tuber appearance (Lambert and Pinto 2002). As biotechnological tools are incorporated in breeding programs, other traits and wild species are going to participate of the cultivated potato germplasm.

Because of natural hybridization, $M$. glaziovii is the most frequently species used in cassava breeding (Lebot 2009). Interspecific hybridization is very difficult in sweet potato, because of crossing incompatibility. Cao et al. (2009) reported novel interspecific hybrids between cultivated sweet potato $(2 n=6 x=90)$ and the two wild diploid $(2 n=2 x=30)$ I. grandifolia and I. purpurea species. The diploid species $I$. triuda is the only self incompatible as sweet potato and produces $2 n$ pollen. It has been used as a source for disease and pest resistance (Lebot 2009).

Besides gene introgression, interspecific hybridization was also involved in the origin of a new horticultural crop. The natural interspecific bybrid combined the fruit size of $F$. chiloensis with the fruit color and flavor of $F$. virginiana to form de octoploid $(2 n=8 x=56)$ cultivated strawberry. The introgression of important traits as unique flavors, vigor, disease and pest resistance and adaptability to a wide range of environmental conditions from wild species with lower ploidy $(2 x, 4 x$ and $6 x)$ levels have been difficulty, because of sterility or low fertility of hybrid combinations. Interspecific octoploids involving these wild species were synthesized and were successfully used as male parents in crosses with cultivated strawberry (Evans 1977).

The introgression of multiple and disable traits from wild species would increase the genetic diversity and the probability of selecting superior clones from single crosses and of identifying important traits in new potato cultivars mainly by chance (Bradshaw 2009). Molecular marker assisted introgression, as showed for late blight resistance in potato, is the key possibility. Conversely, it depends upon the availability of saturated linkage maps and the identification of markers linked to the most important traits. In an optimistic scenario, marker assisted introgression speeds the process of broadening the genetic base, because of the usefulness of selecting to desired traits and against the wild species genome (Hermsen 1994). Therefore, marked assisted introgression is worth for identifying the best hybrid parent and the need for new cycle of backcross to cultivated germoplasm and selection. The marker assisted introgression should get many benefits from genomic resources, like whole genome sequence, large number of expressed sequence tags, large insert genomic libraries, molecular markers and high density genetic maps. The most important projects of genome sequencing of horticultural crops are tomato (www.sgn.cornell.edu/about/tomato), potato (www. potatogenome.net), papaya (www.asgpb.mhpcc. hawaii.edu/papaya) and grapes (www.vitaceae.org). Conversely, compared to cereals and other crops, the progress of genomic studies in horticultural crops is relatively slow (Sonah et al. 2011).

\section{Development of new cultivars}

The objectives vary among horticultural species, breeding programs and final use of the crop. In potato more than 50 traits should be combined in a modern cultivar, including yield (morphological, physiological and ontogenetically factors, adaptation to field growth techniques, harvest and storage), disease and pest resistances, tolerance to environmental factors e quality traits depending upon utilization purposes (Ross 1986). New strawberry cultivars are improved for specific agronomic (yield and size), qualitative (firmness, sugars content and acidity) and sensorial (color and aroma) traits combined to disease resistance and crop adaptability (Capocasa et al. 2008). For cassava and sweet potato, new cultivars should have adaptation to farmer conditions, 
yield stability, extended harvest season, high dry matter content in the storage roots and good eating quality (Lebot 2009).

The development of new cultivars of vegetavely propagated horticultural crops has not been evolving too much. Many breeding efforts remain under funded and disorganized. The main changes have been the scale and the available technology to breeders. Worldwide potato breeding programs still remain empirical and based primarily on phenotypic recurrent selection (Bradshaw and Mackay 1994), a similar breeding scheme of cassava, sweet potato, yams (Lebot 2009) and strawberry (Capocasa et al. 2008). Therefore, there is a great need or a more focused and coordinated approach to efficiently utilize funding, share expertise, and continue progress in horticultural technologies and programs (Dias 2010).

A typical breeding program of vegetatively propagated horticultural crops is conducted as the following scheme. Controlled crosses are made between clones with complementary traits. Progeny of controlled or even open pollination crosses is submitted to phenotypic selection in the field. A strong selection is applied for highly heritable traits. Clonal selection is applied for diseases and pest resistance and quality traits for a few generations. The best clones are also vegetatively propagated for regional and advanced yield trails. Selected clones are them evaluated in official trials of intellectual property rights and cultivar release and also crossed with other superior clones for a new cycle of recurrent selection. In such breeding scheme it could take nine or more years to complete a selection cycle in potato (Bradshaw and Mackay 1994) and six years in cassava (Ceballos et al. 2004). The Scottish Crop Research Institute has a target length of 12 years to get a new potato cultivar. Year 1: crossing selected parents; year 2: grown seedlings in a greenhouse; year 3: single spaced plants at the seed site; year 4: unreplicated small plots at the propagation site; years 5-7; ware yield trials at the breeding station, propagules (seed potato) production of selected clones at the propagation site and disease and quality testing in other sites; years 8-10: multisite trials in Britain and overseas and larger scale production of propagules at the propagation site; years 11-12: national list (official) trials; and year 13: the new cultivar is released and added to the national list (Bradshaw 2009).

As during crop evolution, breeding scheme ensures few possibilities of genetic recombination and many generations of selection and vegetative propagation.
Therefore, the possibilities of increasing scientific and genetic approaches to sophisticate the breeding program are the possibility of selecting best and complementary parents, of increasing progeny size and screening methodology and of associating genetic studies and biotechnological techniques.

Improving clones for crossing should mean gene introgression from wild and unrelated species and improve general combining ability. Parents should also be from complementary groups of germplasm to better exploit yield and heterosis, which are fixed by vegetative propagation. In autopolyploid species, multiplex parents should also be select to improve traits with single dominant gene effect. In potato, a quadruplex for a major resistant gene would ensure a complete resistant progeny, as would be the triplex in the absence of double reduction (Bradshaw and Mackay 1994). The progeny test can be used to identify quadruplex and triplex parents, to discard progenies with poor performance for key traits and to assess the general combining ability based upon mean-progeny performance in crosses with other parents (Bradshaw and Mackay 1994, Bradshaw 2009). Progeny performance in crosses was successfully used to identify parents to combine late blight resistance with tuber processing quality (Bisognin et al. 2002, Bisognin and Douches 2002b). The best progenies and the progeny of parents with high general combining ability are planted in larger population sizes for clonal evaluations. This approach increases the probability of selecting superior clones, because the breeding population has a higher mean performance for the most important traits. Also, sequential selection improves the genetic gain while requires a small number of generations (Lambert et al. 2005).

The continue process of selection reduces the number of evaluated clones, which gives the possibility of increasing the plot size, the range of geographical area, and the number and complexity of evaluated traits. Therefore, higher amount and quality of propagules and more sophisticated trails are necessary to accurately access more genetically complex traits. Besides yield and agronomic performance, the most important diseases and pest reaction and quality traits are also evaluated. In most cases, propagules are produced following good commercial practices to warranty the necessary quality for comparing different clones and conditions. The decision making process of identifying the best clones should be based upon multitrait evaluations, multistage selection theory and genetic parameter estimations (Bradshaw and Mackay 1994). 


\section{DA Bisognin}

With the advent of new sequencing technologies, the number of expressed sequence tags is going to increase very soon. These sequences form an important source for candidate gene discovery, genetic markers, development of microarrays, and even whole genome sequencing (Sonah et al. 2011). As increase the knowledge and the number of molecular markers, breeders can associate marker assisted selection to traditional breeding schemes to increase genetic gain. Molecular markers should be useful for genotyping and selecting complementary parents for crossing and also for identifying superior genotypes at the greenhouse seedling stage. In some cases, the desired allele at a genetic locus can be directly recognized as demonstrate for the RB gene conferring late blight resistance introgressed from S. bulbocastanum (Colton et al. 2006). The molecular cloning and transferring genes of natural resistance and controlling biochemical pathway from wild species to well adapted cultivars would be interesting for safety and market issues. However, the biotechnological advances have been limited at research level and just few cases resulted in commercialization products, mainly for highly cultivated and consumed horticultural crops (Sonah et al. 2011). A high sophistication of the breeding scheme also requires the development of rapid vegetative propagation techniques, since a high number of individuals are needed for multitrait and official trails that are required for cultivar release.

Searching the databases of protected cultivars and the national list of cultivars, we figured out a very diverse situation in terms of cultivar availability. Brazil is highly dependent upon potato and strawberry cultivars developed in other countries. All protected cultivars of strawberry were developed either in the United States (six) or Spain (two). From 57 protected cultivars of potato, only eight were developed in Brazil. In the national list of cultivars, there are 45 strawberry and 145 potato cultivars. There are 66 cassava e 24 sweet potato cultivars at the national list, being all developed by public breeding programs of Brazil. Worldwide, public breeding programs remain a key component of horticultural research systems, especially in developing countries. However, the increasing investments of the private sector in breeding and the decrease of national and international support makes it difficult for the public sector to continue operating in the traditional manner (Dias 2010).

\section{Production of stock plants and rapid vegetative propagation}

The accumulation of deleterious mutations, virus, fungus, bacteria and other pathogens is an important constraint of a continuous vegetative propagation. Because of the devastating effect on agronomic performance, pathogen infection may result in the discard of genetically superior clones and in low yield and quality of a cultivar. Therefore, the genetic, physiological and sanitary quality of the vegetative propagules depend upon the production of disease free stock plants and have an important role in vegetatively propagated horticultural crops.

The tissue culture technique enables to get disease free stock plants and to maximize its multiplication rates, having an enormous impact in the commercial production of horticultural crops. The most important methods are meristem culture, to get disease free explants, and micropropagation of axillary or adventitious shoot buds, to produce millions of identical plants under controlled and aseptic conditions. Somaclonal variation might occur during successive generations of micropropagation, which requires new in vitro establishment and micropropagation cycles to maintain clone fidelity. Rapid ex vitro vegetative propagation was also developed to reduce costs and to increase rate of mass propagation. Cutting techniques have been used in breeding programs of cassava, sweet potato, yam (Lebot 2009), and potato (Bryan 1981). Sweet potato has showed a high rate of somatic mutations in storage roots. Therefore, the vegetative propagation of sweet potato should be preferably done by stem cuttings (Lebot 2009). Technology of vegetative propagation is also available as public domain at worldwide patent databases.

Although the available and very promising technology of rapid propagation, most applications are still restricted to breeding programs. Besides the dependence for cultivars, farmers also depend upon importation of high quality propagules. Strawberry plantlets are imported from Argentine and Chile. Seed potatoes have been imported from Netherlands, Canada and Chile and, more recently, from France and Scotland. Importation is mandatory because it is not possible to produce and propagate all cultivars necessary to attend the demand and the quality for commercial production. There are still several steps of which require simplifications and adaptations for the rapid propagation technology to be easily adopted by small holders and commercial growers, even for potato and 
strawberry crops. We are currently developing and adapting rapid propagation techniques, but it is still confidential information.

\section{CONCLUDING REMARKS}

Many horticultural crops are vegetatively propagated to explore the advantages of high uniformity and hybrid vigor. Some species are also among the oldest on earth and they are a very important set of food crops, promoting diversification and providing nutritional and food security.

The possibility of combining sexual and asexual reproduction systems in almost all vegetatively propagated horticultural crops is very important for both broaden the genetic base and developing new cultivars. The inter and intraspecific hybridization are the best approach to increase the genetic base of cultivated germoplasm and the crossability with related wild species, and to combine traits in one individual. Besides that, hybridization also increases the genetic diversity for traits less or still not exploited in breeding programs and to reduce the genetic vulnerability of these crops.

The development of new cultivars is based upon phenotypic recurrent selection. The incorporation of biotechnology techniques to sophisticate the breeding programs might be a possibility only for highly cultivated and consumed horticultural crops. Molecular markers should be useful for genotyping and selecting complementary parents for crossing and also for identifying superior genotypes at the first generation of selection.

Species with higher funds for research have the totality or the majority of the protected cultivars developed in other countries. These species also depends upon high quality propagules produced in other countries, which results in low availability and high cost and dependence for commercial production in Brazil. This scenario is a consequence of the globalization; because the most breeding programs of horticultural crops in the world are conducted and funded in the private sector, mainly by huge multinational seed companies (Dias 2010). Therefore, public investments should be done to make rapid propagation techniques available to small holders and commercial producers to reduce the production costs and to increase yield, quality and food security, at least for crops as cassava and sweet potato.

\section{ACKNOWLEDGEMENTS}

The author is very grateful to the graduate students, professors and other researchers of the Crop Breeding and Vegetative Propagation Group (http://www.ufsm.br/ mpvp). I also thank CNPq, for the scholarship, and $\mathrm{CNPq}$ and FAPERGS, for the financial support of the Potato Breeding Program.

\section{Melhoramento de hortaliças de propagação vegetativa}

RESUMO - A horticultura é uma importante área da agricultura, sendo que muitas espécies são propagadas via vegetativa. Os objetivos deste trabalho foram discutir algumas das características mais importantes das culturas de propagação vegetativa e as estratégias de melhoramento para desenvolver e multiplicar novas cultivares. A propagação vegetativa possibilita fixar imediatamente as combinações mais favoráveis de caracteres importantes, as composições químicas específicas, as interações genéticas superiores e o alto nível de heterozigose. O desenvolvimento de novas cultivares envolve poucas possibilidades de recombinação genética por hibridação e muitas gerações de seleção e propagação vegetativa. Seleção assistida por marcadores moleculares deverá ser aplicada para a identificação de genótipos complementares para cruzamento e de genótipos superiores nas primeiras gerações de seleção. A cultura de tecidos possibilita a produção de plantas matrizes livres de doenças e maximiza a taxa de multiplicação, tendo um papel fundamental para o aumento da produtividade e qualidade destas culturas.

Palavras-chave: culturas de raízes e tubérculos, micropropagação, propagação rápida, selação clonal, novas cultivares.

\section{REFERENCES}

Bisognin DA and Douches DS (2002a) Genetic diversity in diploid and tetraploid late blight resistant potato germplasm. Hortscience 36: 178-183.
Bisognin DA and Douches DS (2002b) Early generation selection for potato tuber quality in progenies of late blight resistant parents. Euphytica 127: 1-9. 


\section{DA Bisognin}

Bisognin DA, Douches DS, Jastrzebski K and Kirk WW (2002) Half-sib progeny evaluation and selection of potatoes resistant to the US8 genotype of Phytophthora infestans from crosses between resistant and susceptible parents. Euphytica 125: 129 138 .

Bisognin DA, Douches DS, Buszka L, Bryan G and Wang D (2005) Mapping late blight resistance in Solanum microntum Bitter. Crop Science 45: 340-345.

Bryan JE (1981) Rapid Multiplication techniques for potatoes. International Potato Center, Lima, 20p.

Bradshaw JE (1994) Quantitative genetics theory for tetrasomic inheritance. In Bradshaw JE and GR Mackay (eds.) Potato genetics. CABI, Cambridge, p. 71-99.

Bradshaw JE and Mackay GR (1994) Breeding strategies for clonally propagated potatoes. In Bradshaw JE and GR Mackay (eds.) Potato genetics. CABI, Cambridge, p. 467-497.

Bradshaw JE (2009) Potato breeding at the Scottish Plant Breeding Station and the Scottish Crop Research Institute: 1920-2008. Potato Research 52: 141-172

Bredmose N and Hansen J (1996) Topophysis aûects the potential of axillary bud growth, fresh biomass accumulation and specific fresh weight in single-stem roses (Rosa hybrida L.). Annals of Botany 78: 215-222.

Cao Q, Zhang A, Ma D, Li H, Li Q and Li P (2009) Novel interspeciûc hybridization between sweet potato (Ipomoea batatas (L.) Lam.) and its two diploid wild relatives. Euphytica 169: $345-352$.

Capocasa F, Diamanti J, Tulipani S, Battino M and Mezzetti B (2008) Breeding strawberry (Fragaria X ananassa Duch) to increase fruit nutritional quality. BioFactors 34: 67-72.

Ceballos H, Iglesias CA, Pérez JC and Dixon AGO (2004) Cassava breeding: opportunities and challenges. Plant Molecular Biology 56: 503-516.

Colton LM, Groza HI, Wielgusand SM and Jiang J (2006) Markerassisted selection for the broad-spectrum potato late blight resistance conferred by gene $\mathrm{RB}$ derived from a wild potato species. Crop Science 46: 589-594.

Dias JCS (2010) Impact of improved vegetable cultivars in overcoming food insecurity. Euphytica 176: 125-136.

Douches DS, Bamberg JB, Kirk WW, Jastrzebski BA, Niemira BA, Coombs J, Bisognin DA and Walters-felcher K (2001) Evaluation of wild Solanum species for resistance to the US8 genotype of Phytophthora infestans utilizing a fine-screening technique. American Journal of Potato Research 78: 159165 .

Eckert CG (2002) The loss of sex in clonal plants. Evolutionary Ecology 15: 501-520.
Evans WD (1977) The use of synthetic octoploids in strawberry breeding. Euphytica 26: 497-503.

Glémin S, Bazin E and Charlesworth D (2006) Impact of mating systems on patterns of sequence polymorphism in ûowering plants. Proceedings of the Royal Society Series B Biological Sciences 273: 3011-3019.

Hancock JF (2004) Plant evolution and the origin of crop species. CABI, Cambridge, $313 \mathrm{p}$.

Hanneman RE Júnior (1999) The reproductive biology of the potato and its implications for breeding. Potato Research 42: 283-312.

Hawkes JG and Jackson MT (1992) Taxonomic and evolutionary implications of the endosperm balance number hypothesis in potatoes. Theoretical and Applied Genetics 84: 180-185.

Hawkes JG (1990) The potato: evolution, biodiversity and genetic resources. Belhaven Press, London, 259p.

Hermsen JGT (1994) Introgression of genes from wild species, including molecular and cellular approaches. In Bradshaw JE and Mackay GR (ed.) Potato genetics. CABI, Cambridge, p. 71-99.

Jablonka E and Raz G (2009) Transgenerational epigenetic inheritance: prevalence, mechanisms, and implications for the study of heredity and evolution. Quarterly Review of Biology 84: 131-176.

Klaehn FU (1963) The relationship of vegetative propagation to topophysis, cyclophysis and periphysis in forest trees. In Proceedings of the $10^{\text {th }}$ northeastern forest tree improvement conference. Durham, p. 42-50.

Lambert ES and Pinto CABP (2002) Agronomic performance of potato interspecific hybrids. Crop Breeding and Applied Biotecnology 2: 179-188.

Lambert ES, Pinto CABP and Simon GA (2005) Sequential selection of potato clones. Breeding and Applied Biotecnology 5: $149-156$.

Lebot V (2009) Tropical root and tuber crops: cassava, sweet potato, yams, aroids. CABI, Cambridge, 413p. (Crop production science in horticulture series 17)

McKey D, Elias M, Pujol B and Duputié A (2010) The evolutionary ecology of clonally propagated domesticated plants. New Phytologist 186: 318-332.

Nybom N (1961) The use of induced mutations for the improvement of vegetatively propagated plants. In Symposium in mutation and plant breeding. National Academy of Science - National Research Council, Washington, p. 252-294. (Publication 891)

Ross H (1986) Potato breeding - problems and perspectives. Paul Parey, Berlin and Hamburg, 132p. (Advances in plant breeding series 13 ) 
Breeding vegetatively propagated horticultural crops

Sonah H, Deshmukh RK, Singh VP, Gupta DK, Singh NK and Sharma TR (2011) Genomic resources in horticultural crops: status, utility and challenges. Biotechnology Advances 29: 199-209.
Zohary D (2004) Unconscious selection and the evolution of domesticated plants. Economic Botany 58: 5-10. 